\title{
Biological and Genetic Diversity of Wheat yellow mosaic virus (Genus Bymovirus)
}

\author{
Takehiro Ohki, Osamu Netsu, Hisayo Kojima, Junichi Sakai, Masatoshi Onuki, \\ Tetsuo Maoka, Yukio Shirako, and Takahide Sasaya
}

First and sixth authors: NARO Hokkaido Agricultural Research Center. Hitsujigaoka, Toyohira-ku, Sapporo, Hokkaido, 062-8555, Japan; second author: Department of Agricultural and Environmental Biology, University of Tokyo, Yayoi, Bunkyo-ku, Tokyo 113-8657; third author: NARO Institute of Crop Science, Kannondai, Tsukuba, Ibaraki 305-8666, Japan; fourth, fifth, and eighth authors: NARO Kyushu Okinawa Agricultural Research Center, Suya, Koshi, Kumamoto 861-1192, Japan; and seventh author: Asian Center for Bioresources and Environmental Sciences (ANESC), University of Tokyo, Yayoi, Bunkyo-ku, Tokyo 113-8657.

Accepted for publication 25 September 2013.

\begin{abstract}
Ohki, T., Netsu, O., Kojima, H., Sakai, J., Onuki, M., Maoka, T., Shirako, Y., and Sasaya, T. 2014. Biological and genetic diversity of Wheat yellow mosaic virus (genus Bymovirus). Phytopathology 104:313-319.

The biological and genetic diversity of Wheat yellow mosaic virus (WYMV) isolates in Japan was characterized. On the basis of wheat cultivar reactions, $14 \mathrm{WYMV}$ isolates from various places were classified into pathotypes I, II, or III. These were distributed in central, northern, and southern areas of Japan, respectively. WYMV isolates comprised three genotypes (A, $\mathrm{A}^{\prime}$ and $\mathrm{B}$ ) based on amino acid differences in RNA1

correlation was found between the WYMV RNA1-based genotype and pathotype, suggesting that factors associated with pathogenicity map to RNA1. Genotype Aa and A'a were distributed mainly in the central to southern areas of Japan, and genotype $\mathrm{Bb}$ was found in northern areas of Japan, as shown by reverse-transcription polymerase chain reaction restriction fragment length polymorphism analysis. Chinese isolates YA and $\mathrm{YZ}$ were closely related to genotypes $\mathrm{Bb}$ and $\mathrm{Aa}$, respectively. Wheat was introduced from China to Japan in the 4th and 5th centuries, and the two genotypes of WYMV might also have been introduced with the crop from China and later adapted to local wheat cultivars in Japan.
\end{abstract} and two genotypes ( $a$ and $b$ ) based on amino acid differences in RNA2. A
Wheat yellow mosaic virus (WYMV) causes yellow mosaic and dwarf symptoms on wheat (Triticum aestivum L.) and causes yield losses of $>30 \%$ in wheat in Japan. WYMV was first identified in Japan and has been reported in China and Japan $(6,8)$. A similar yellow mosaic disease on wheat is caused by Wheat spindle streak mosaic virus (WSSMV) in North America, Europe, and Africa $(10,24,26,27,33,35)$. These viruses belong to the genus Bymovirus in the family Potyviridae. The virions are flexuous filaments with two modal lengths $(\approx 550$ and $275 \mathrm{~nm})$ and a diameter of $13 \mathrm{~nm}$. They contain two linear, positive-sense, single-strand RNAs $(31,32)$. The complete sequence of WYMV has been determined for Japanese isolate JA (17) and two Chinese isolates, YA and YZ (3). RNA1 is $\approx 7.7 \mathrm{~kb}$ long and encodes a polyprotein that contains the coat protein and seven putative nonstructural proteins: $\mathrm{P} 3,7 \mathrm{~K}$, cylindrical-shaped inclusion protein $(\mathrm{CI}), 14 \mathrm{~K}$, genome-linked viral protein (VPg), protease (Pro), and RNA-dependent RNA polymerase (NIb). RNA2 is $\approx 3.7 \mathrm{~kb}$ long and encodes a polyprotein that contains a $28-\mathrm{kDa}$ protein (P1) and a 73-kDa protein (P2). WYMV and WSSMV are transmitted by the soil-inhabiting Polymyxa graminis and have similar host ranges that are restricted to Hordeum spp. However, because of the low amino acid sequence identity of their coat proteins, WYMV and WSSMV are classified as distinct Bymovirus spp. $(4,17,28,36)$.

Control measures for the yellow mosaic disease caused by WYMV have included cultural practices, chemical treatments,

Corresponding author: T. Sasaya; E-mail address: tsasaya@affrc.go.jp

* The $\boldsymbol{e}$-Xtra logo stands for "electronic extra" and indicates that the online version contain three supplemental tables.

http://dx.doi.org/10.1094/PHYTO-06-13-0150-R

(C) 2014 The American Phytopathological Society and introduction of resistant cultivars. However, resting spores of $P$. graminis, which can carry and transmit the virus, can remain viable in the soil for a long period, and recommended cultural practices such as crop rotations and late fall plantings of wheat seed do not adequately control the disease (2). Chemical fumigation of the soil can be effective but is not a realistic option because the fungicide is too expensive for wheat production.

Thus, introducing resistant cultivars is considered the most effective method to control the disease. The development of WYMV-resistant cultivars requires ongoing analysis for resistance genes in wheat. Thus far, the dominant resistance genes $Y m Y F, Y m I b$, and $Y m M D$ have been mapped on the long arm of chromosome 2D of Chinese wheat 'Yangfu 9311', European wheat 'Ibis', and American wheat 'Madsen', respectively (14,20, 30). In an analysis of microsatellite (simple-sequence repeat) markers these resistance genes were found to be closely related but no evidence was provided as to whether any of these three genes are the same. The quantitative trait locus associated with resistance to WYMV, QYm.njau-5A.1, was mapped on the long arm of chromosome 5A of 'Xifeng' wheat, and DNA markers that closely link with QYm.njau-5A.1 were found (38). In addition to these dominant resistance genes, three or four recessive genes also seem to be involved in WYMV resistance (7). With the use of these DNA markers linked to WYMV-resistance genes, the development of the new WYMV-resistance cultivars should be accelerated.

In contrast to advances in resistance against WYMV, analysis of the viral factors and the mechanism involved in virulence of WMYV have not progressed as much. Pathological differences among WYMV isolates have been reported in Japan and China $(3,12,22)$. To help elucidate the viral factors involved in the virulence of WYMV isolates, Chen et al. (3) compared genomic sequences among WYMV isolates that induced different reactions 
on various wheat cultivars but viral factors remain to be identified. For effective progress in breeding resistant cultivars, it is very important to clarify the interaction between wheat resistance genes and viral factors.

In this study, we examined the biological and genetic diversity of WYMV in Japan to advance our understanding of population structure and obtain useful information for wheat breeding programs.

\section{MATERIALS AND METHODS}

Sampling and assay for WYMV pathotype. To investigate host reactions and genomic sequences of WYMV, we collected leaves of one wheat tiller with yellow mosaic symptoms from 14 locations among 10 prefectures in Japan during 2009 and 2010 (Table 1; Fig. 1) and stored them at $-80^{\circ} \mathrm{C}$ until use. WYMV has no local lesion host plants, and a single lesion isolation experiment could not be conducted. To confirm whether more than one WYMV was present in the wheat samples, we preliminarily sequenced the partial coat protein region of WYMV from three to five wheat samples from each field of the 14 locations in Japan. Because mixed-wave peaks were barely observable by direct sequencing, we assumed that the wheat samples did not include more than one WYMV and considered them to be WYMV isolates.

The pathotypes of 14 isolates were determined based on the reactions of 'Nambukomugi', 'Fukuhokomugi', and 'Hokkai 240' wheat (Table 1) after mechanical inoculation of leaves dusted with carborundum and inoculum prepared by grinding leaves in $50 \mathrm{mM}$ phosphate buffer $(\mathrm{pH}$ 7.0). After plants were held in the dark for 5 to 7 days at $5^{\circ} \mathrm{C}$, plants were maintained in a screenhouse for 1 to 2 months in the winter. Infection with WYMV was confirmed by symptom expression and double-antibody sandwich enzyme-linked immunosorbent assay (ELISA) (18).

Total RNA extraction, cDNA synthesis, sequencing, and phylogenetic analysis. Leaf samples were ground in 2-ml microfuge tubes with a sterile 4-mm stainless steel grinding ball and powdered by adding liquid nitrogen and shaking at 15,000 rpm for 5 min with a Multi-Beads Shocker (Yasui Kikai Corp., Osaka, Japan). Total RNA was extracted using an RNeasy Plant Mini Kit (Qiagen, Valencia, CA). First-strand cDNA was synthesized using SuperScript III (Invitrogen, Carlsbad, CA) and a random 6-mer primer according to the manufacturer's recommendations. In all, $\approx 0.2 \mu \mathrm{g}$ of total RNA and $100 \mathrm{ng}$ of primer were denatured at $65^{\circ} \mathrm{C}$ for $5 \mathrm{~min}$ and incubated on ice for $2 \mathrm{~min}$. After adding reagents, the reactions were incubated at room temperature for $5 \mathrm{~min}, 50^{\circ} \mathrm{C}$ for $1 \mathrm{~h}$, and $70^{\circ} \mathrm{C}$ for $10 \mathrm{~min}$, then incubated at $37^{\circ} \mathrm{C}$ for 20 min with $40 \mathrm{U}$ of RNase H (Takara Bio, Shiga, Japan). The mixtures were diluted 1:2.5 water for experimental use. The coding regions of the 14 isolates were amplified by KOD plus polymerase (Toyobo, Osaka, Japan). The primers for amplification and sequencing were designed based on nucleotide sequences of the JA isolate (accessions D86634 and D86635). The 5' and 3' untranslated regions (UTRs) of four isolates (Chitose, Morioka, Tsukuba, and Yanagawa) were determined. The 5' UTR was amplified by rapid amplification of cDNA ends methods according to Weng and Xiong (34). The 3' UTR was amplified using the natural poly(A) tail. The polymerase chain reaction (PCR) products were treated with $2.5 \mathrm{U}$ of exonuclease I (Takara Bio) and $0.25 \mathrm{U}$ of shrimp alkaline phosphatase (Takara Bio) at $37^{\circ} \mathrm{C}$ for $20 \mathrm{~min}$ and $80^{\circ} \mathrm{C}$ for $30 \mathrm{~min}$, then cleaned with a QIAquick PCR Purification Kit (Qiagen). The PCR products were directly sequenced using a BigDye Terminator v1.1 Cycle-Sequencing Kit (Applied Biosystems, Foster City, CA) with an ABI PRISM 3100 Genetic Analyzer (Applied Biosystems). The nucleotide sequences of full-length or coding regions from the 14 WYMV isolates were registered in the DDBJ database (RNA1 accessions: AB627806 to AB627819 and RNA2: AB627821 to AB627834, respectively). The nucleotide and amino acid sequences of isolates JA, YA (AJ239039 and AJ242490), and YZ (AJ131981 and

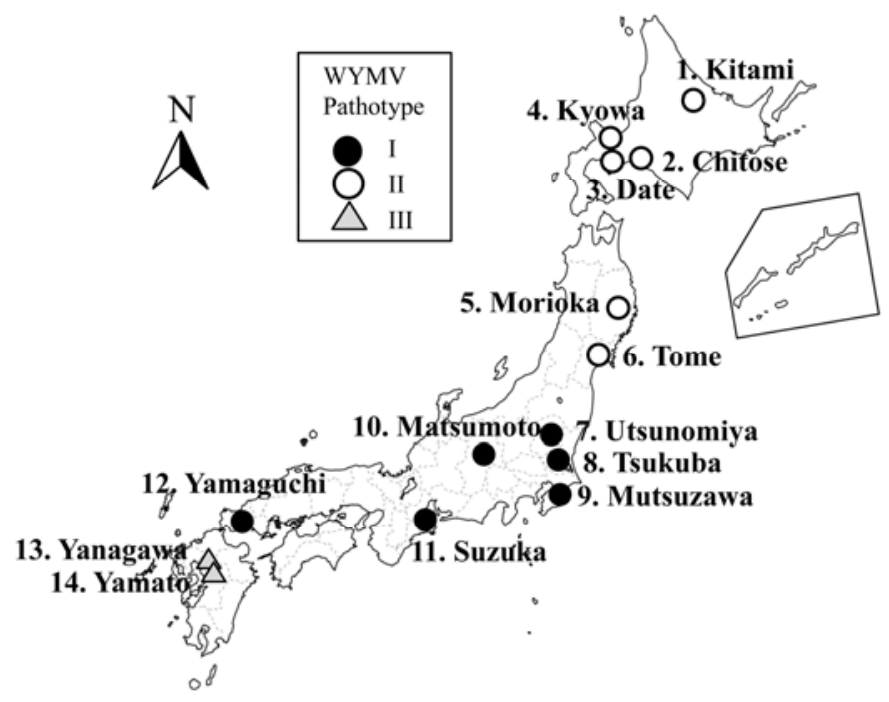

Fig. 1. Distribution in Japan of pathotypes of Wheat yellow mosaic virus used in this study. Pathotypes I, II, and III are distributed in central, northern, and southern areas of Japan, respectively.

TABLE 1. Pathotypes of Japanese isolates of Wheat yellow mosaic virus (WYMV) isolates determined using three wheat cultivars in this study

\begin{tabular}{|c|c|c|c|c|c|}
\hline \multirow[b]{2}{*}{ Isolate name } & \multirow[b]{2}{*}{ Prefecture of origin } & \multicolumn{3}{|c|}{ Cultivar (number of infected/total inoculated) } & \multirow[b]{2}{*}{ Pathotype $^{\mathrm{a}}$} \\
\hline & & Nambukomugi & Fukuhokomugi & Hokkai 240 & \\
\hline Kitami & Hokkaido & $8 / 21$ & $0 / 25$ & $0 / 24$ & II \\
\hline Chitose & Hokkaido & $26 / 47$ & $0 / 42$ & $0 / 44$ & II \\
\hline Date & Hokkaido & $5 / 23$ & $0 / 32$ & $1 / 16^{\mathrm{b}}$ & II \\
\hline Kyowa & Hokkaido & $24 / 44$ & $0 / 41$ & $2 / 35^{b}$ & II \\
\hline Morioka & Iwate & $31 / 43$ & $0 / 42$ & $0 / 41$ & II \\
\hline Tome & Miyagi & $13 / 20$ & $0 / 22$ & $0 / 23$ & II \\
\hline Utsunomiya & Tochigi & $30 / 44$ & $13 / 43$ & $0 / 41$ & I \\
\hline Tsukuba & Ibaraki & $27 / 40$ & $18 / 43$ & $0 / 42$ & I \\
\hline Mutsuzawa & Chiba & $18 / 44$ & $27 / 44$ & $0 / 44$ & I \\
\hline Matsumoto & Nagano & $8 / 23$ & $13 / 23$ & $0 / 16$ & I \\
\hline Suzuka & Mie & $3 / 23$ & $10 / 22$ & $0 / 20$ & I \\
\hline Yamaguchi & Yamaguchi & $10 / 45$ & $32 / 44$ & $0 / 41$ & I \\
\hline Yanagawa & Fukuoka & $9 / 29$ & $7 / 18$ & $10 / 20$ & III \\
\hline Yamato & Fukuoka & $6 / 25$ & $6 / 20$ & $4 / 11$ & III \\
\hline
\end{tabular}

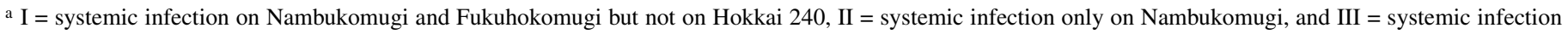
on all three cultivars.

b WYMV infected but did not cause symptoms. 
AJ131982) were obtained from the database. The identities among WYMV isolates were calculated with GENETYX software (Genetyx Corp., Tokyo). For phylogenetic analysis, the coding regions were aligned with ClustalX software ver. 2.0 (13) then a phylogenetic tree was constructed using the same software and the neighbor-joining method (bootstrap $=1,000$ replicates).

Restriction fragment length polymorphism. For reversetranscription (RT)-PCR restriction fragment length polymorphism (RFLP), three primer pairs were designed based on the alignment of 14 isolates of WYMV (Supplemental Table 1). On the basis of amino acid sequences specific to genotypes of WYMV, restriction enzymes NheI, Aor51HI, and TaqI (Takara Bio) were selected. Digestion of PCR products with WR-F1/-R1, WR-F2/-R2, and WR-F3/-R3 indicated genotype $A$ or $A^{\prime}$ for RNA1, genotype $A^{\prime}$ for RNA1, and genotype a for RNA2, respectively. The cDNA was synthesized in the same way as for the sequencing analysis, and PCR was performed using KOD dash polymerase (Toyobo). The $25 \mu$ l of mixture was prepared with $1 \times$ KOD dash buffer, $0.2 \mathrm{mM}$ dNTPs, $0.2 \mu \mathrm{M}$ each primer, $0.625 \mathrm{U}$ of KOD dash, and $0.5 \mu \mathrm{l}$ of the cDNA reactions. The amplification conditions were 30 cycles of $94^{\circ} \mathrm{C}$ for $20 \mathrm{~s}, 55^{\circ} \mathrm{C}$ for $15 \mathrm{~s}$, and at $74^{\circ} \mathrm{C}$ for $20 \mathrm{~s}$. For digestion by the restriction enzymes, $10 \mu \mathrm{l}$ of mixture was prepared with $2.5 \mu \mathrm{l}$ of PCR reaction, $1 \times$ enzyme buffer, $0.01 \%$ bovine serum albumen, and $2 \mathrm{U}$ of a restriction enzyme. The mixtures were incubated at $37^{\circ} \mathrm{C}$ for $2 \mathrm{~h}$ with NheI and Aor $51 \mathrm{HI}$ or at $65^{\circ} \mathrm{C}$ for $2 \mathrm{~h}$ with $\mathrm{TaqI}$, and the products were separated on a $2 \%$ agarose gel in $1 \times$ Tris-acetate-EDTA buffer at $100 \mathrm{~V}$ for $30 \mathrm{~min}$ and visualized with ethidium bromide. Some PCR products that were not digested with proper restriction enzymes were cloned by a TOPO TA Cloning kit (Invitrogen), and the sequence confirmed as mentioned already.

\section{RESULTS}

Distribution of WYMV pathotypes in Japan. On the basis of the reaction of Nambukomugi, Fukuhokomugi, and Hokkai 240 wheat, the 14 isolates of WYMV from various places in Japan were grouped into pathotypes I, II, or III (Table 1). Isolates from Utsunomiya, Tsukuba, Mutsuzawa, Matsumoto, Suzuka, and Yamaguchi prefectures were classified as pathotype I, which causes a systemic infection on Nambukomugi and Fukuhokomugi but not on Hokkai 240. The Kitami, Chitose, Date, Kyowa,
Morioka, and Tome isolates were classified as pathotype II, which causes a systemic infection only on Nambukomugi. Two isolates, Yanagawa and Yamato, were classified as pathotype III, which caused infection on all three wheat cultivars. Data showed a geographical component to the distribution of the three pathotypes (Fig. 1). WYMV isolates of pathotype II were found in northern areas of Japan, pathotype I in the central areas of Japan, and pathotype III in southern areas of Japan.

The JA isolate of WYMV was previously found to be pathotype I (22). Although Chinese isolates YA and YZ were reported to differ in their host reactions (3), we could not presume the pathotypes of the two Chinese isolates because the wheat cultivars used for determination of the pathotypes by Chen et al. (3) differed from ours.

Comparison of genomic sequence. The nucleotide sequence of the entire genome of 4 isolates of WYMV (Chitose, Morioka, Tsukuba, and Yanagawa) and the coding regions of the 10 other isolates were determined and compared with those of JA, YA, and $\mathrm{YZ}$ isolates previously reported. The coding regions on RNA1 of 17 isolates, including JA, YA, and YZ, consisted of 7,215 nucleotides (nt) and encoded a polyprotein of 2,404 amino acids. The coding region of 14 isolates of WYMV on RNA2 comprised 2,712 nt and 903 amino acids, 1 amino acid shorter than those of isolates JA, YA, and YZ. The coding region for RNA1 and RNA2 among 17 WYMV isolates shared high amino acid identities (>96.2 and $93.1 \%$ respectively) (Supplemental Table 2). The 5' UTR of four isolates was $162 \mathrm{nt}$ long in RNA1 and $172 \mathrm{nt}$ in RNA2. The 3' UTR was $258 \mathrm{nt}$ long in RNA1 and $767 \mathrm{nt}$ long in RNA2, except for the polyA tail. The $5^{\prime}$ and $3^{\prime}$ UTR shared identities of $>90.1$ and $97.3 \%$ in RNA1 and 89.9 and $98.7 \%$ in RNA2, respectively (Supplemental Table 3).

Comparison of amino acids among isolates. On the basis of amino acid differences in the coding region of RNA1 and RNA2, WYMV isolates were divided into several genetic variants (Tables 2 and 3). WYMV grouped into genotypes $\mathrm{A}, \mathrm{A}^{\prime}$, and $\mathrm{B}$ based on RNA1 amino acid composition (Table 2). Genotypes A and B differed in 13 characteristic amino acids, mainly located within the CI, VPg, Pro, and NIb regions. The sequence of genotype $\mathrm{A}^{\prime}$ was similar to that of genotype A, with only four amino acid differences (Table 2); $A^{\prime}$ is likely to have derived from A. The phylogenetic analysis using nucleotide sequences of the coding regions of WYMV RNA1 also confirmed a close relationship

TABLE 2. Characteristic amino acids at various positions correlated with the genotype of Wheat yellow mosaic virus in RNA ${ }^{\mathrm{a}}$

\begin{tabular}{|c|c|c|c|c|c|c|c|c|c|c|c|c|c|c|c|c|c|c|}
\hline \multirow[b]{3}{*}{ Isolate } & \multirow[b]{3}{*}{ Pathotype $^{\mathrm{b}}$} & \multirow[b]{3}{*}{ Genotype $^{c}$} & \multicolumn{16}{|c|}{ Position of amino acid } \\
\hline & & & \multirow{2}{*}{$\begin{array}{c}\mathrm{P} 3 \\
228^{\mathrm{d}}\end{array}$} & \multicolumn{9}{|c|}{$\mathrm{CI}$} & \multirow{2}{*}{$\frac{14 \mathrm{~K}}{1095}$} & \multirow{2}{*}{$\frac{\mathrm{VPg}}{1318}$} & \multicolumn{2}{|c|}{ Pro } & \multicolumn{2}{|c|}{$\mathrm{NIb}$} \\
\hline & & & & 397 & 418 & 421 & 443 & 655 & $679^{d}$ & 820 & 1017 & 1040 & & & 1468 & 1540 & 1587 & 1828 \\
\hline Kitami & II & B & $\mathrm{H}$ & $\mathrm{N}$ & D & $\mathbf{A}$ & $\mathbf{L}$ & $\mathbf{R}$ & $\mathbf{N}$ & $\mathbf{V}$ & V & $\mathbf{T}$ & $\mathbf{L}$ & $\mathbf{K}$ & I & $\mathbf{S}$ & I & $\mathbf{K}$ \\
\hline Chitose & II & B & $\mathrm{H}$ & $\mathrm{N}$ & D & $\mathbf{A}$ & $\mathbf{L}$ & $\mathbf{R}$ & $\mathbf{N}$ & $\mathbf{V}$ & V & $\mathbf{T}$ & $\mathbf{L}$ & $\mathbf{K}$ & I & $\mathbf{S}$ & I & $\mathbf{K}$ \\
\hline Date & II & B & $\mathrm{H}$ & $\mathrm{N}$ & D & $\mathbf{A}$ & $\overline{\mathbf{L}}$ & $\mathbf{R}$ & $\mathbf{N}$ & $\mathbf{V}$ & V & $\mathbf{T}$ & $\mathbf{L}$ & $\mathbf{K}$ & I & $\mathbf{S}$ & I & $\mathbf{K}$ \\
\hline Kyowa & II & B & $\mathrm{H}$ & $\mathrm{N}$ & D & $\mathbf{A}$ & $\mathbf{L}$ & $\mathbf{R}$ & $\mathbf{N}$ & $\mathbf{V}$ & V & $\mathbf{T}$ & $\mathbf{L}$ & $\mathbf{K}$ & I & $\mathbf{S}$ & I & $\mathbf{K}$ \\
\hline Morioka & II & $\mathrm{B}$ & $\mathrm{H}$ & $\mathrm{N}$ & D & $\mathbf{A}$ & $\mathbf{L}$ & $\mathbf{R}$ & $\mathbf{N}$ & $\mathbf{V}$ & V & $\mathbf{T}$ & $\mathbf{L}$ & $\mathbf{K}$ & I & $\mathbf{S}$ & I & $\mathbf{K}$ \\
\hline Tome & II & $\mathrm{B}$ & $\mathrm{H}$ & $\mathrm{N}$ & D & $\mathbf{A}$ & $\mathbf{L}$ & $\mathbf{R}$ & $\mathbf{N}$ & $\mathbf{V}$ & V & $\mathbf{T}$ & $\mathbf{L}$ & $\mathbf{K}$ & I & $\mathbf{S}$ & I & $\mathbf{K}$ \\
\hline Utsunomiya & $\mathrm{I}$ & A & $\mathrm{H}$ & $\mathrm{N}$ & $\mathrm{E}$ & $\mathrm{T}$ & I & $\mathrm{K}$ & $\mathrm{S}$ & I & V & I & $\mathrm{F}$ & $\mathrm{T}$ & $\mathrm{L}$ & $\mathrm{T}$ & $\mathrm{T}$ & $\mathrm{R}$ \\
\hline Tsukuba & I & A & $\mathrm{H}$ & $\mathrm{N}$ & $\mathrm{E}$ & $\mathrm{T}$ & I & $\mathrm{K}$ & $\mathrm{S}$ & I & V & I & $\mathrm{F}$ & $\mathrm{T}$ & $\mathrm{L}$ & $\mathrm{T}$ & $\mathrm{T}$ & $\mathrm{R}$ \\
\hline Mutsuzawa & I & A & $\mathrm{H}$ & $\mathrm{N}$ & $\mathrm{E}$ & $\mathrm{T}$ & I & $\mathrm{K}$ & $\mathrm{S}$ & I & V & I & $\mathrm{F}$ & $\mathrm{T}$ & $\mathrm{L}$ & $\mathrm{T}$ & $\mathrm{T}$ & $\mathrm{R}$ \\
\hline Matsumoto & I & A & $\mathrm{H}$ & $\mathrm{N}$ & $\mathrm{E}$ & $\mathrm{T}$ & I & $\mathrm{K}$ & $\mathrm{S}$ & I & V & I & $\mathrm{F}$ & $\mathrm{T}$ & $\mathrm{L}$ & $\mathrm{T}$ & $\mathrm{T}$ & $\mathrm{R}$ \\
\hline Suzuka & I & A & $\mathrm{H}$ & $\mathrm{N}$ & $\mathrm{E}$ & $\mathrm{T}$ & I & $\mathrm{K}$ & $\mathrm{S}$ & I & V & I & $\mathrm{F}$ & $\mathrm{T}$ & $\mathrm{L}$ & $\mathrm{T}$ & $\mathrm{T}$ & $\mathrm{R}$ \\
\hline Yamaguchi & I & $\mathrm{A}$ & $\mathrm{H}$ & $\mathrm{N}$ & $\mathrm{E}$ & $\mathrm{T}$ & I & $\mathrm{K}$ & $\mathrm{S}$ & I & V & I & $\mathrm{F}$ & $\mathrm{T}$ & $\mathrm{L}$ & $\mathrm{T}$ & $\mathrm{T}$ & $\mathrm{R}$ \\
\hline Yanagawa & III & $\mathrm{A}^{\prime}$ & $R$ & $G$ & $\mathrm{E}$ & $\mathrm{T}$ & I & $\mathrm{K}$ & $\mathrm{S}$ & I & $L$ & I & $\mathrm{F}$ & $K$ & $\mathrm{~L}$ & $\mathrm{~T}$ & $\mathrm{~T}$ & $\mathrm{R}$ \\
\hline Yamato & III & $\mathrm{A}^{\prime}$ & $R$ & $G$ & $\mathrm{E}$ & $\mathrm{T}$ & I & $\mathrm{K}$ & $\mathrm{S}$ & I & $L$ & I & $\mathrm{F}$ & $K$ & $\mathrm{~L}$ & $\mathrm{~T}$ & $\mathrm{~T}$ & $\mathrm{R}$ \\
\hline JA & I & A & $\mathrm{H}$ & $\mathrm{N}$ & $\mathrm{E}$ & $\mathrm{T}$ & I & $\mathrm{K}$ & $\mathrm{S}$ & I & V & I & $\mathrm{F}$ & $\mathrm{T}$ & $\mathrm{L}$ & $\mathrm{T}$ & $\mathrm{T}$ & $\mathrm{R}$ \\
\hline YA & n.d. & B & $\mathrm{H}$ & $\mathrm{H}$ & D & $\mathbf{A}$ & $\mathbf{L}$ & $\mathbf{R}$ & $\mathbf{N}$ & $\mathbf{V}$ & V & $\mathbf{T}$ & $\mathbf{L}$ & $\mathrm{T}$ & $\mathrm{L}$ & $\mathbf{S}$ & I & $\mathbf{K}$ \\
\hline $\mathrm{YZ}$ & n.d. & A & $\mathrm{H}$ & $\mathrm{N}$ & $\mathrm{E}$ & $\mathrm{T}$ & I & $\mathrm{K}$ & $\mathrm{S}$ & I & V & I & $\mathbf{L}$ & $\mathrm{T}$ & $\mathrm{L}$ & $\mathrm{T}$ & $\mathrm{T}$ & $\mathrm{K}$ \\
\hline
\end{tabular}

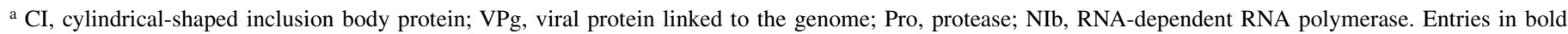
have characteristic amino acids correlated with genotype B and those in italics have $\mathrm{A}^{\prime}$.

b Abbreviation: n.d. = not determined.

c Sequences from Tsukuba, Morioka and Yanagawa isolates are named genotype A, B, and A', respectively.

d Amino acid targeted in restriction fragment length polymorphism analysis. 
between genotypes $\mathrm{A}$ and $\mathrm{A}^{\prime}$ (Fig. 2). Fourteen WYMV isolates were divided into two clades; all six isolates in genotype B belonged to one clade, and six isolates in genotype $\mathrm{A}$ and two isolates in genotype $\mathrm{A}^{\prime}$ belonged to the other clade. With regard to a correlation between genotype and pathotype, genotype $\mathrm{A}, \mathrm{B}$, and $\mathrm{A}^{\prime}$ on RNA1 corresponded to pathotype I, II, and III, respectively.

WYMV isolates grouped into genotypes a and $\mathrm{b}$ based on RNA2 amino acid composition (Table 3). Twelve amino acids, mainly located on P2, were different between both genotypes. Genotype $\mathrm{a}$ and $\mathrm{b}$ on RNA2 generally linked to pathotype I and II, respectively. However, the RNA2 of the Matsumoto isolate indicated that pathotype I belongs to genotype b. In addition, no amino acid substitutions related to pathotype III were found on

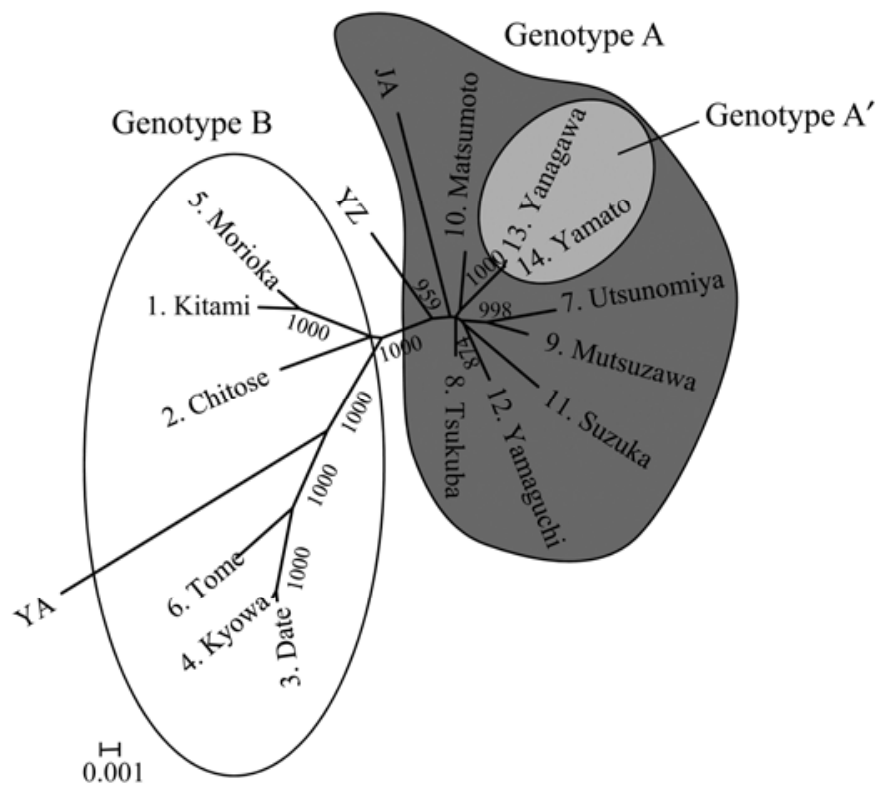

Fig. 2. Unrooted phylogenetic analysis based on nucleotide sequences of RNA1 of 14 isolates of Wheat yellow mosaic virus in Japan. Unrooted phylogenetic tree was constructed using the neighbor-joining (NJ) method (bootstrap $=1,000$ replicates). Only bootstrap values $>700$ are shown. Bar indicates phylogenetic distance.
RNA2. Therefore, these results strongly suggested that WYMV RNA1 rather than RNA2 contains the viral factors associated with the pathotype.

Of 14 isolates, 7 were either genotype Aa or $\mathrm{A}^{\prime} \mathrm{a}, 6$ were $\mathrm{Bb}$, and only 1 was the reassortant genotype $\mathrm{Ab}$. Interestingly, the Chinese isolates YA and YZ of WYMV also agreed well with the amino acid specificity for genotypes (Tables 2 and 3); isolate YA isolate was close to genotype $\mathrm{Bb}$ and $\mathrm{YZ}$ was close to genotype Aa.

Analysis of genotype by RT-PCR-RFLP. To examine the distribution of each genotype in Japan, we designed an RT-PCRRFLP to characterize each genotype. Genotypes A, $A^{\prime}$, and B on RNA1 were assessed by the digestion pattern of PCR products obtained with primer pair WR-F1/-R1 and NheI and primers WR-

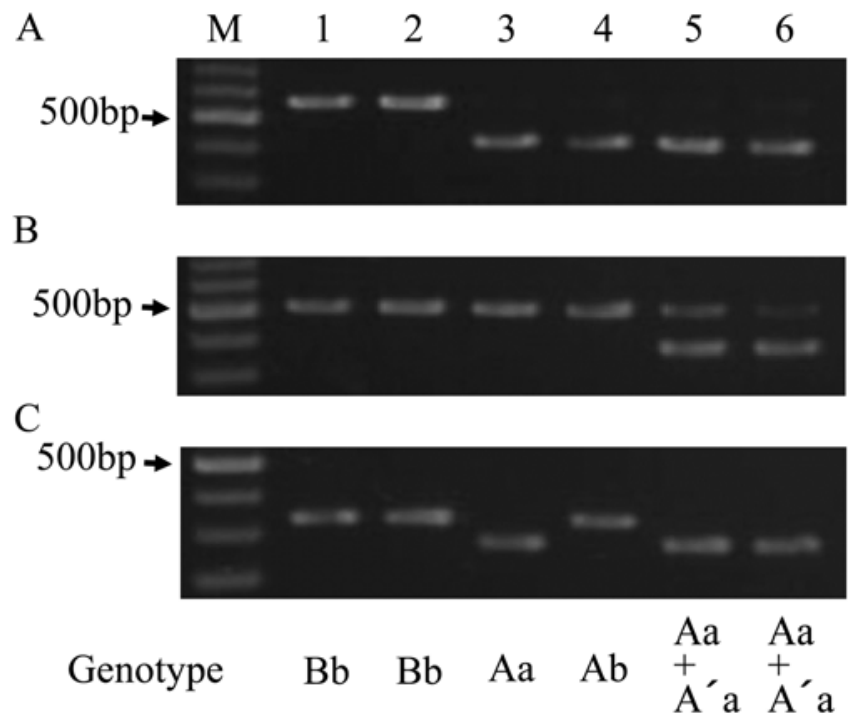

Fig. 3. Determination of genotype using reverse-transcription polymerase chain reaction restriction fragment length polymorphism. Bands $\mathbf{A}$, amplified with primer WR-F1/-R1 and digested with NheI; B, amplified with WR-F2/-R2 and digested with Aor51HI; and C, amplified with WR-F3/-R3 and digested with TaqI. Lane M, 100-bp DNA ladder (Toyobo); and wheat samples from lane 1, Kitami; lane 2, Date; lane 3, Utsunomiya; lane 4, Matsumoto; lane 5, Yanagawa; and lane 6, Yamato.

TABLE 3. Characteristic amino acids at various positions correlated with the genotype of Wheat yellow mosaic virus in RNA2 ${ }^{\mathrm{a}}$

\begin{tabular}{|c|c|c|c|c|c|c|c|c|c|c|c|c|c|c|}
\hline \multirow[b]{3}{*}{ Isolate } & \multirow[b]{3}{*}{ Pathotype $^{b}$} & \multirow[b]{3}{*}{ Genotype $^{c}$} & \multicolumn{12}{|c|}{ Position of amino acid } \\
\hline & & & \multirow{2}{*}{$\frac{\mathrm{P} 1}{51}$} & \multicolumn{11}{|c|}{$\mathrm{P} 2$} \\
\hline & & & & $261^{\mathrm{d}}$ & 267 & 274 & 305 & 315 & 358 & 359 & 364 & 369 & 474 & 509 \\
\hline Kitami & II & $\mathrm{b}$ & $\mathbf{G}$ & $\mathbf{Q}$ & $\mathbf{F}$ & $\mathbf{T}$ & $\mathbf{Y}$ & $\mathbf{N}$ & $\mathbf{H}$ & $\mathbf{S}$ & $\mathbf{S}$ & $\mathbf{I}$ & $\mathbf{N}$ & $\mathbf{F}$ \\
\hline Chitose & II & b & $\mathbf{G}$ & $\mathbf{Q}$ & $\mathbf{F}$ & $\mathbf{T}$ & $\mathbf{Y}$ & $\mathbf{N}$ & $\mathbf{H}$ & $\mathbf{S}$ & $\mathbf{S}$ & $\mathbf{I}$ & $\mathbf{N}$ & $\mathbf{F}$ \\
\hline Date & II & $\mathrm{b}$ & $\mathbf{G}$ & $\mathbf{Q}$ & $\mathbf{F}$ & $\mathbf{T}$ & $\mathbf{Y}$ & $\mathbf{N}$ & $\mathbf{H}$ & $\mathbf{S}$ & $\mathbf{S}$ & I & $\mathbf{N}$ & $\mathbf{F}$ \\
\hline Kyowa & II & $\mathrm{b}$ & $\mathbf{G}$ & $\mathbf{Q}$ & $\mathbf{F}$ & $\mathbf{T}$ & $\mathbf{Y}$ & $\mathbf{N}$ & $\mathbf{H}$ & $\mathbf{S}$ & $\mathbf{S}$ & I & $\mathbf{N}$ & $\mathbf{F}$ \\
\hline Morioka & II & b & $\mathbf{G}$ & $\mathbf{Q}$ & $\mathbf{F}$ & $\mathbf{T}$ & $\mathbf{Y}$ & $\mathbf{N}$ & $\mathbf{H}$ & $\mathbf{S}$ & $\mathbf{S}$ & I & $\mathbf{N}$ & $\mathbf{F}$ \\
\hline Tome & II & $\mathrm{b}$ & $\mathbf{G}$ & $\mathbf{Q}$ & $\mathbf{F}$ & $\mathbf{T}$ & $\mathbf{Y}$ & $\mathbf{N}$ & $\mathbf{H}$ & $\mathbf{S}$ & $\mathbf{S}$ & I & $\mathbf{N}$ & $\mathbf{F}$ \\
\hline Utsunomiya & I & a & $\mathrm{S}$ & $\mathrm{R}$ & $\mathrm{S}$ & A & $\mathrm{R}$ & G & $\mathrm{Y}$ & $\mathrm{N}$ & $\mathrm{P}$ & V & $\mathrm{S}$ & I \\
\hline Tsukuba & I & $\mathrm{a}$ & $\mathrm{S}$ & $\mathrm{R}$ & S & A & $\mathrm{R}$ & G & $\mathrm{Y}$ & $\mathrm{N}$ & $\mathrm{P}$ & $\mathrm{V}$ & $\mathrm{S}$ & I \\
\hline Mutsuzawa & I & a & $\mathrm{S}$ & $\mathrm{R}$ & $\mathrm{S}$ & A & $\mathrm{R}$ & G & $\mathrm{Y}$ & $\mathrm{N}$ & $\mathrm{P}$ & $\mathrm{V}$ & $\mathrm{S}$ & I \\
\hline Matsumoto & I & $\mathrm{b}$ & $\mathbf{G}$ & $\mathbf{Q}$ & $\mathbf{F}$ & $\mathbf{T}$ & $\mathbf{Y}$ & $\mathbf{N}$ & $\mathbf{H}$ & $\mathbf{S}$ & $\mathbf{S}$ & I & $\mathbf{N}$ & $\mathbf{F}$ \\
\hline Suzuka & I & a & $\mathrm{S}$ & $\mathrm{R}$ & $\mathrm{S}$ & A & $\mathrm{R}$ & G & $\mathrm{Y}$ & $\mathrm{N}$ & $\mathrm{P}$ & V & $\mathrm{S}$ & I \\
\hline Yamaguchi & I & a & $\mathrm{S}$ & $\mathrm{R}$ & $\mathrm{S}$ & A & $\mathrm{R}$ & G & $\mathrm{Y}$ & $\mathrm{N}$ & $\mathrm{P}$ & V & $\mathrm{S}$ & I \\
\hline Yanagawa & III & $\mathrm{a}$ & $\mathrm{S}$ & $\mathrm{R}$ & $\mathrm{S}$ & A & $\mathrm{R}$ & G & $\mathrm{Y}$ & $\mathrm{N}$ & $\mathrm{P}$ & V & $\mathrm{S}$ & I \\
\hline Yamato & III & $\mathrm{a}$ & S & $\mathrm{R}$ & $\mathrm{S}$ & A & $\mathrm{R}$ & G & $\mathrm{Y}$ & $\mathrm{N}$ & $\mathrm{P}$ & V & $\mathrm{S}$ & I \\
\hline JA & I & a & $\mathrm{S}$ & $\mathrm{R}$ & $\mathrm{S}$ & A & $\mathrm{R}$ & G & $\mathrm{Y}$ & $\mathrm{N}$ & $\mathrm{P}$ & V & $\mathrm{S}$ & I \\
\hline YA & n.d. & $\mathrm{b}$ & $\mathbf{G}$ & $\mathbf{Q}$ & $\mathbf{F}$ & $\mathbf{T}$ & $\mathbf{Y}$ & $\mathbf{N}$ & $\mathrm{N}$ & $\mathbf{S}$ & $\mathbf{S}$ & I & $\mathbf{N}$ & $\mathbf{F}$ \\
\hline YZ & n.d. & $\mathrm{a}$ & $\mathrm{S}$ & $\mathrm{R}$ & $\mathrm{S}$ & A & $\mathrm{R}$ & $\mathrm{G}$ & $\mathrm{Y}$ & $\mathrm{N}$ & $\mathrm{P}$ & V & $\mathrm{S}$ & $\mathrm{F}$ \\
\hline
\end{tabular}

${ }^{a}$ Entries in bold have characteristic amino acids correlated with genotype $b$.

b Abbreviation: n.d. $=$ not determined.

c Sequences from Tsukuba and Morioka are named genotype $\mathrm{a}$ and $\mathrm{b}$.

d Amino acid targeted in restriction fragment length polymorphism analysis. 
F2/-R2 and Aor $51 \mathrm{HI}$; and genotypes a and b on RNA2 using primers WR-F3/-R3 and TaqI. Representative RFLP patterns of WYMV isolates from six places are shown in Figure 3. Wheat samples from Kitami, Date, Utsunomiya, and Matsumoto indicated genotypes $\mathrm{Bb}, \mathrm{Bb}, \mathrm{Aa}$, and $\mathrm{Ab}$, respectively. Wheat samples from Yanagawa and Yamato correspond to a mixed infection of genotypes Aa and A'a on RNA1 (Fig. 3, lanes 5 and 6). Isolates from Yanagawa and Yamato had mixed infections of genotypes A and $\mathrm{A}^{\prime}$ but they were classified into pathotype III because wheat samples dually infected with genotypes Aa and A'a, would yield results for pathotype III.

More WYMV isolates from various areas in Japan were characterized by RT-PCR-RFLP (Table 4). Samples from northern areas of Japan (Kitami, Chitose, Date, Kyowa, and Morioka) were all genotype $\mathrm{Bb}$. In samples from Tome, genotype $\mathrm{Bb}$ was generally detected as well, although a few samples had Ab genotypes. In the central areas of Japan, except for Matsumoto, almost all samples were genotype Aa. The virus with reassortant genotype $\mathrm{Ab}$ seemed to be widely distributed in Matsumoto and less so in Suzuka. In the southern areas (Yamaguchi, Yanagawa, and
Yamato), genotypes Aa and A'a were detected in the same fields. Genotype Ba was not found in the present study. In summary, WYMV genotypes Aa/A'a and Bb were the primary genotypes in Japan, and WYMV of the reassortant genotype was mainly observed in Matsumoto.

\section{DISCUSSION}

Here, we characterized the genetic diversity and pathogenicity of WYMV isolates in Japan. Cultivar inoculation tests showed three WYMV pathotypes. This result is consistent with those of Ohto et al. (22). When genomic sequences of WYMV were grouped into genotypes based on their characteristic amino acids (Tables 2 and 3 ) and compared with the pathotypes, the genotype based on RNA1 coincided with each pathotype. Therefore, differences of pathogenicity map to amino acids encoded by WYMV RNA1.

WYMV isolates of pathotype II do not usually infect Hokkai240 wheat systemically. However, the Date and Kyowa isolates did systemically infect Hokkai240 (Table 1). There is a possibility that WYMV isolates of pathotypes II and III had co-infected the

TABLE 4. Analysis of genotype of Wheat yellow mosaic virus RNA1 and RNA2 by reverse-transcription polymerase chain reaction restriction fragment length polymorphism

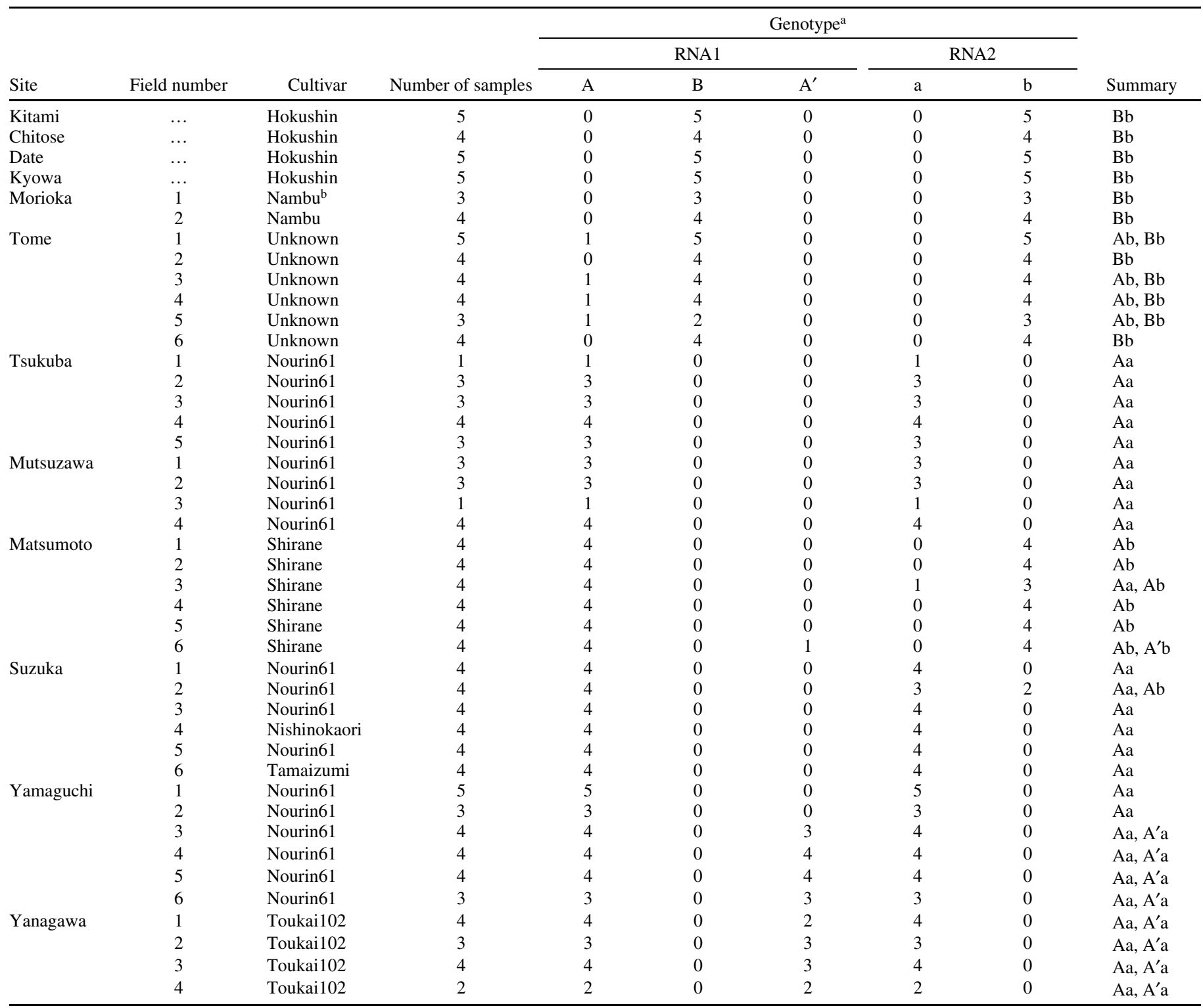

a Co-infection by two genotypes was detected in some samples.

b Nambu, Nambukomugi; Shirane, Shiranekomugi. 
samples but the infection rate and the absorbance values of ELISA were very low (data not shown). In addition, the isolates did not systemically infect Fukuhokomugi and did not induce any symptoms on Hokkai240, thus clearly differing from pathotype III. RFLP analysis of samples from Date and Kyowa described in this article also negated the possibility of co-infection in their samples.

Compared with other potyviruses, genetic diversity of WYMV was low. WYMV isolates collected in this experiment shared nucleotide and amino acid identities of $>97.3$ and $98.0 \%$ for RNA1 and 95.8 and $96.1 \%$ for RNA2, respectively. In contrast, nucleotide identities of Japanese isolates of Bean yellow mosaic virus (BYMV) were $>75.8 \%$ (16). One of reasons for this low diversity may be the restricted host range of WYMV. The natural host of WYMV is limited to wheat but BYMV causes severe diseases in many leguminous and ornamental plants. When the nucleotide sequences of Turnip mosaic virus (TuMV) were compared after propagating in the host of origin and in a different host, the nucleotide diversity and the nonsynonymous/synonymous ratio of TuMV on the different host were higher than those on the original host (21). Barley yellow mosaic virus (BaYMV), which belongs to the same genus, Bymovirus, and only infects barley naturally, also showed low genetic divergence and shared an amino acid identity greater than $97.1 \%$ on RNA1 and $95.0 \%$ on RNA2 for Japanese isolates (19).

Differences in RNA1 amino acid composition were mainly found in CI, VPg, Pro, and NIb (Table 2). Chen et al. (3) also reported variable parts in the CI- and NIb-coding regions of RNA1 among JA, YZ, and YA isolates of WYMV. The CI protein is a structural protein of cytoplasmic cylindrical inclusion bodies formed during infection that is assumed to possess helicase activities (17). VPg, a genome-linked viral protein that attaches to the $5^{\prime}$ terminus of genomic RNAs, interacts with the host translation machinery (23). Pro and NIb are assumed to be a protease involved in polyprotein processing and an RNA-dependent RNA polymerase, respectively. Reverse genetic experiments identified the $\mathrm{C}$ terminus of gene $\mathrm{CI}$ as the elicitor of extreme resistance or hypersensitive reaction for Lettuce mosaic virus, Soybean mosaic virus, and TuMV $(1,5,25)$. A single amino acid substitution in the $\mathrm{C}$ terminus enabled the virus to overcome resistance. In barley, barley eukaryotic translation initiation factor 4E (Hv-eIF4E) was identified as one of the recessive resistance genes to BaYMV and Barley mild mosaic virus (29), and the VPg was involved in virulence determination $(9,11)$. There is no direct information on the viral factors that are involved in virulence and determination of WYMV pathotypes. However, a reverse genetic system for the genus Bymovirus was recently developed (37); therefore, future experiments should help determine which genomic regions of WYMV are involved in virulence and pathogenicity.

The distribution of the three pathotypes (that is, the distribution of the three WYMV RNA1 genotypes) may be partially due to the cultivars grown in local areas of Japan. Cultivars resistant to WYMV pathotype II, such as 'Nourin 61' and Fukuhokomugi, have been traditionally cultivated in central to southern areas of Japan. Therefore, pathotype II may have been excluded while pathotype I prevailed in these areas. The preferred use of certain cultivars might also explain why WYMV pathotype III would be derived from pathotype I. By cultivation of cultivars resistant to pathotype I, such as 'Shiroganekomugi', in the southern areas, a certain pathotype I virus might mutate and gain the ability to overcome cultivar resistance. In our phylogenetic analysis using nucleotide sequences of the coding region of WYMV RNA1, WYMV isolates in genotypes A (pathotype I) and $A^{\prime}$ (pathotype III) clustered in the same clade (Fig. 2). In addition, RFLP analysis showed that genotypes $\mathrm{A}$ and $\mathrm{A}^{\prime}$ occurred together in the same area of Japan. The prevalence of pathotype II in the northern areas of Japan is not known for certain. However, our preliminary experiments indicate that the resistance of pathotype I can change depending on the temperature. Nambukomugi wheat that is cultivated mainly in northern Japan was susceptible to pathotypes I and II in our experiment (Table 1). However, the cultivar showed resistance to pathotype $I$ at a relatively high temperature (13 to $15^{\circ} \mathrm{C}$ ) and was susceptible at a relatively low temperature. Thus, the temperature-sensitivity of the cultivar might influence the prevalence of pathotype II in the northern areas.

RT-PCR-RFLP was useful in examining the distribution of WYMV genotypes. Genotypes Aa and Bb of WYMV are mainly distributed in Japan and reassortant isolates such as genotype $\mathrm{Ab}$ are infrequent (Table 4). One reason may be that WYMVs with genotypes $\mathrm{Aa}$ or $\mathrm{Bb}$ were separately introduced to Japan. Wheat is thought to have originated in the Mideast and Near East $\approx 7,000$ B.C.E. and been transported to China $\approx 2,000$ B.C.E. It was then introduced to Japan in the 4th to 5th centuries through two routes, directly from southeast China or via the Korean Peninsula, and spread throughout Japan (15). The characteristic amino acids of each genotype were correlated with those of either isolates YA or $\mathrm{YZ}$. Isolate $\mathrm{YZ}$ is closely related to genotype Aa, found in central Japan, and YA isolate is closely related to genotype $\mathrm{Bb}$ in northern Japan (Tables 2 and 3). The occurrence of WYMV is limited to Japan and China and has not spread to other areas. These results lead us to predict that two genotypes of WYMV, which originated in China, were separately introduced to Japan from China, adapted to local cultivars, and thus became established in Japan.

\section{LITERATURE CITED}

1. Abdul-Razzak, A., Guiraud, T., Peypelut, M., Walter, J., Houvenaghel, M.-C., Candresse, T., Le Gall, O., and German-Retana, S. 2009. Involvement of the cylindrical inclusion (CI) protein in the overcoming of an eIF4E-mediated resistance against Lettuce mosaic potyvirus. Mol. Plant Pathol. 10:109-113.

2. Adams, M. J. 1990. Epidemiology of fungally-transmitted viruses. Soil Use Manage. 6:184-189.

3. Chen, J., Chen, J.-P., Yang, J.-P., Cheng, Y., Diao, A., Adams, M. J., and Du, J. 2000. Differences in cultivar response and complete sequence analysis of two isolates of wheat yellow mosaic bymovirus in China. Plant Pathol. 49:370-374.

4. Chen, J., Sohn, A., Chen, J.-P., Lei, J., Cheng, Y., Schulze, S., Steinbiss, H.-H., Antoniw, J. F., and Adams, M. J. 1999. Molecular comparisons amongst wheat bymovirus isolates from Asia, North America and Europe. Plant Pathol. 48:642-647.

5. Fujiwara, A., Inukai, T., Kim, B. M., and Masuta, C. 2011. Combinations of a host resistance gene and the CI gene of turnip mosaic virus differentially regulate symptom expression in Brassica rapa cultivars. Arch. Virol. 156:1575-1581.

6. Han, C., Li, D., Xing, Y., Zhu, K., Tian, Z., Cai, Z., Yu, J., and Liu, Y. 2000. Wheat yellow mosaic virus widely occurring in wheat (Triticum aestivum) in China. Plant Dis. 84:627-630.

7. Hatta, K., Ohto, Y., Nakamura, K., Ito, S., and Yoshikawa, R. 1997. Inheritance of resistance to wheat yellow mosaic virus (WYMV) in doubled haploid lines of wheat (Triticum aestivum L.). Proc. Ninth Int. Wheat Genet. Symp. 3:276-278

8. Inoue, T. 1969. Filamentous particles as the causal agent of yellow mosaic disease of wheat. Nogaku Kenkyu 53:61-68 (in Japanese).

9. Kanyuka, K., McGrann, G., Alhudaib, K., Hariri, D., and Adams, M. J. 2004. Biological and sequence analysis of a novel European isolate of Barley mild mosaic virus that overcomes the barley rym 5 resistance gene. Arch. Virol. 149:1469-1480.

10. Kapooria, R. G., Ndunguru, J., and Clover, G. R. G. 2000. First reports of Soilborne wheat mosaic virus and Wheat spindle streak mosaic virus in Africa. Plant Dis. 84:921.

11. Kühne, T., Shi, N., Proeseler, G., Adams, M. J., and Kanyuka, K. 2003. The ability of a bymovirus to overcome the rym4-mediated resistance in barley correlates with a codon change in the VPg coding region on RNA1. J. Gen. Virol. 84:2853-2859.

12. Kusume, T., Tamada, T., Hattori, H., Tsuchiya, T., Kubo, K., Abe, H., Namba, S., Tsuchizaki, T., Kishi, K., and Kashiwazaki, S. 1997. Identification of a new wheat yellow mosaic virus strain with specific pathogenicity towards major wheat cultivars grown in Hokkaido. Ann. Phytopathol. Soc. Jpn. 63:107-109.

13. Larkin, M. A., Blackshields G., Brown, N. P., Chenna, R., McGettigan, P. A., McWilliam, H., Valentin, F., Wallace, I. M., Wilm, A., Lopez, R., 
Thompson, J. D., Gibson, T. J., and Higgins, D. G. 2007. Clustal W and Clustal X version 2.0. Bioinformatics 23:2947-2948.

14. Liu, W., Nie, H., Wang, S., Li, X., He, Z., Han, C., Wang, J., Chen, X., Li, L., and Yu, J. 2005. Mapping a resistance gene in wheat cultivar Yangfu 9311 to yellow mosaic virus, using microsatellite markers. Theor. Appl. Genet. 111:651-657.

15. Nakamura, H. 2008. Possible transmission route for common wheat to the far east in Asia. Crop Sci. 48:1117-1123.

16. Nakazono-Nagaoka, E., Takahashi, T., Shimizu, T., Kosaka, Y., Natsuaki, T., Omura, T., and Sasaya, T. 2008. Cross-Protection Against Bean yellow mosaic virus (BYMV) and Clover yellow vein virus by Attenuated BYMV Isolate M11. Phytopathology 99:251-257.

17. Namba, S., Kashiwazaki, S., Lu, X., Tamura, M., and Tsuchizaki, T. 1998. Complete nucleotide sequence of wheat yellow mosaic bymovirus genomic RNAs. Arch. Virol. 143:631-643.

18. Netsu, O., Ohki, T., Kojima, H., Oda, S., Aoki, E., Yoshioka, T., Yanagisawa, T., Ishikawa, K., and Sasaya, T. 2011. Development of serological diagnosis by ELISA for specific detection of four soil-borne viruses in wheat (Triticum aestivum) and barley (Hordeum vulgare). Annu. Rep. Kanto-Tosan Plant Prot. Soc. 58:13-17. (In Japanese)

19. Nishigawa, H., Hagiwara, T., Yumoto, M., Sotome, T., Kato, T., and Natsuaki, T. 2008. Molecular phylogenetic analysis of Barley yellow mosaic virus. Arch. Virol. 153:1783-1786.

20. Nishio, Z., Kojima, H., Hayata, A., Iriki, N., Tabiki, T., Ito, M., Yamauchi, H., and Murray, T. D. 2010. Mapping a gene conferring resistance to Wheat yellow mosaic virus in European winter wheat cultivar 'Ibis' (Triticum aestivum L.). Euphytica 176:223-229.

21. Ohshima, K., Akaishi, S., Kajiyama, H., Koga, R., and Gibbs, A. J. 2010. Evolutionary trajectory of turnip mosaic virus populations adapting to a new host. J. Gen. Virol. 91:788-801.

22. Ohto, Y., Hatta, K., and Ishiguro, K. 2006. Differential wheat cultivars to discriminate pathogenicity of Japanese wheat yellow mosaic virus (WYMV) isolates. Jpn. J. Phytopathol. 72:93-100. (In Japanese)

23. Robaglia, C., and Caranta, C. 2006. Translation initiation factors: a weak link in plant RNA virus infection. Trends Plant Sci. 11:40-45.

24. Rubies-Autonell, C., and Vallega, V. 1987. Observations on a mixed soilborne wheat mosaic virus and wheat spindle streak mosaic virus infection in durum wheat (Triticum durum Desf.). J. Phytopathol. 119:111-121.

25. Seo, J.-K., Lee, S.-H., and Kim, K.-H. 2009. Strain-specific cylindrical inclusion protein of Soybean mosaic virus elicits extreme resistance and a lethal systemic hypersensitive response in two resistant soybean cultivars. Mol. Plant-Microbe Interact. 22:1151-1159.
26. Slykhuis, J. T. 1970. Factors determining the development of wheat spindle streak mosaic caused by a soil-borne virus in Ontario. Phytopathology 60:319-331.

27. Slykhuis, J. T. 1976. Wheat spindle streak mosaic virus. CMI/AAB Descriptions of Plant Viruses Number 167. Published online by the Association of Applied Biologists, Warwick, U.K

28. Sohn, A., Schenk, P., Signoret, P. A., Schmitz, G., Schell, J., and Steinbiss, H. H. 1994. Sequence analysis of the 3 '-terminal half of RNA 1 of wheat spindle streak mosaic virus. Arch. Virol. 135:279-292.

29. Stein, N., Perovic, D., Kumlehn, J., Pellio, B., Stracke, S., Streng, S., Ordon, F., and Graner, A. 2005. The eukaryotic translation initiation factor 4E confers multiallelic recessive Bymovirus resistance in Hordeum vulgare (L.). Plant J. 42:912-922.

30. Takeuchi, T., Munekata, S., Suzuki, T., Senda, K., Horita, H., Araki, K., Asayama, S., and Sato, M. 2010. Breeding wheat lines resistant to wheat yellow mosaic virus and localization of the resistance gene (YmMD) derived from wheat cultivar 'Madsen'. Breed. Res. 12:1-8. (In Japanese)

31. Usugi, T., Kashiwazaki, S., Omura, T., and Tsuchizaki, T. 1989. Some properties of nucleic acids and coat proteins of soil-borne filamentous viruses. Ann. Phytopathol. Soc. Jpn. 55:26-31. (In Japanese)

32. Usugi, T., and Saito, Y. 1979. Relationship between wheat yellow mosaic virus and wheat spindle streak mosaic virus. Ann. Phytopathol. Soc. Jpn. 45:397-400. (In Japanese)

33. Vaïanopoulos, C., Legreve, A., Moreau, V., Steyer, S., Maraite, H., and Bragard, C. 2005. Occurrence of bymo- and furoviruses on wheat in Belgium. Parasitica 6:47-53.

34. Weng, Z., and Xiong, Z. 1995. A method for accurate determination of terminal sequences of viral genomic RNA. Genome Res. 5:202-207.

35. Wiese, M. V., Saari, E. E., Clayton, J., and Ellingboe, A. H. 1970. Occurrence of wheat streak mosaic and a new variegation disorder, wheat spindle streak mosaic, in Michigan wheat. Plant Dis. Rep. 54:635-637.

36. Xiaoyun, L., Kashiwazaki, S., Tamura, M., and Namba, S. 1998. The 3' terminal sequence of RNA1 of wheat spindle streak mosaic virus Canadian isolate (WSSMV-C). Eur. J. Plant Pathol. 104:765-768.

37. You, Y., and Shirako, Y. 2010. Bymovirus reverse genetics: requirements for RNA2-encoded proteins in systemic infection. Mol. Plant Pathol. 11:383-94.

38. Zhu, X., Wang, H., Guo, J., Wu, Z., Cao, A., Bie, T., Nie, M., You, F. M., Cheng, Z., Xiao, J., Liu, Y., Cheng, S., Chen, P., and Wang, X. 2012. Mapping and validation of quantitative trait loci associated with wheat yellow mosaic bymovirus resistance in bread wheat. Theor. Appl. Genet. 124:177-188. 